Eskişehir Osmangazi Üniversitesi

Sosyal Bilimler Dergisi

Haziran 2019, 20(1), 17-36

DOI: 10.17494/ogusbd.595096

\title{
Evcimenlik Kültünden Çalışan Anneye: Annelik İdeoloji- leri Üzerine Bir Değerlendirme
}

\author{
Eda KILIÇ
}

Evcimenlik Kültünden Çalışan Anneye: Annelik İdeolojileri Üzerine Bir Değerlendirme

\section{Özet}

Anneliğin toplumsal inşası üzerinde hâkim olan yaklaşım, kadınların yaşamını özel alanla sınırlandıran evcimenlik kültüdür. $\mathrm{Bu}$ ideoloji, farklı ideolojiler ile sentezlenerek yoğun annelik ideolojisine dönüşmüştür. 0-14 yaş arası çocuğu olan annelerin istihdam oranlarının OECD ortalamasının son elli yılda iki katına çıkması ise tam zamanlı anneliği savunan yoğun annelik ideolojisinin dönüşüme uğradığının bir göstergesidir. Bu çalışmada, ilgili dönüşüm, anneliğin inşasında etkili ideolojiler ve OECD verileri incelenerek değerlendirmeye tabi tutulmuştur. Bulgular yaşanan dönüşümün temelinde, çalışma hayatının annelik ile uyumlu hale getirilmesine olanak tanıyan yasal düzenlemeler ve çocuk bakım hizmetlerinin genişlemesi gerektiğini göstermiştir. Değerlendirme sonuçları, geçmiş yıllarda birçok toplumda etkisi hissedilen yoğun annelik ideolojisinin aşınarak annelik ve çalışma hayatının bir arada yürütüldüğü yeni bir dengeye doğru evirildiğine işaret etmektedir.

Anahtar Kelimeler: Evcimenlik Kültü, Yoğun Annelik, Annelik İdeolojileri, Çalışan Anne, Toplumsal Cinsiyet Eşitsizliği
From The Cult of Domesticity to the Working Mother: An Evaluation on Maternity Ideologies

\section{Abstract}

The dominant approach on the social construction of motherhood is the cult of domesticity that limits the lives of women to the private sphere. This ideology has been synthesized by different ideologies and transformed into an ideology of intensive motherhood. The fact that the employment rates of mothers with children aged 0-14 years doubled by the OECD average in the last fifty years is an indicator of the transformation of the intensive motherhood ideology that advocates full-time motherhood, as well. In this study, this transformation was evaluated by examining the ideologies effecting the construction of motherhood and OECD data. Evidences show that the basis of aforementioned transformation is the legal arrangements that allow the harmonization of working life with motherhood and the expansion of childcare services. The evaluation results indicate that the intensive ideology of motherhood that influenced many societies in the past years was eroded and developed towards a new balance of motherhood and working life.

Key Words: Cult of Domesticity, Intensive Mothering, Maternity Ideologies, Maternal Employment, Working Mother, Gender Inequality

\section{Giriş}

İnsanlık tarihinin başlangııından itibaren varlı̆ı̆ı sürdüren annelik olgusu; neslin devamını sağlayan biyolojik bir durum olmanın çok ötesinde farklı toplumlarda farklı annelik tezahürleri,

*Eda KILIÇ, Dokt.Öğr., Uludağ Üniversitesi, Sosyal Bilimler Enstitüsü, Çalışma Ekonomisi ve Endüstri iliş̧kileri Anabilim Dalı, edaakademik@gmail.com; ORCID ID orcid.org / 0000-0001-7075-0315 
farklı annelik algıları, anneliğe yüklenen farklı anlamlar ve beklentiler nedeniyle sosyolojik araştırmaların odaklarından birisi olmuştur. Annelik olgusuna dair kültürel algı, bu olguya toplumsal olarak atfedilen değer ve anlamın yanı sıra o toplumda hâkim hale gelmiş farklı ideolojilerin etkisi ile oluşmaktadır. Bu annelik ideolojilerinin hâkim hale gelmesi ise anneliğin toplumsal inşasını sağlamıştır. Bu ideolojilerin incelenmesi, özellikle son yirmi yılda yüzyıllar boyunca kadınların yalnızca anne olarak kabul gördüğü algısının aşınarak çalışma hayatında da var olduklarını kanıtlayan eğilimler ışığında, toplumsal bağlamda anneliğin geçirmiş olduğu dönüşümü göstermek açısından önem arz etmektedir.

Annelik ideolojilerini incelemek için, anneliğin yalnızca biyolojik bir gerçekliğe ya da toplumsal bir tanımlamaya indirgenemeyeceğini, toplumsal ve tarihsel bir yapılanma olduğunu kabul etmek yerinde olacaktır (Bassin, Honey ve Kaplan, 1996; Glenn, 1994; Risman, 1998).

Tarih boyunca farklı toplum ve kültürlerde kadınlığın inşası her kültürün kendine has sözlü yasaları, gelenekleri ve görenekleri ile gerçekleşmiştir. Diğer taraftan 19. yüzyılda yaşanan sanayileşme sürecine eşlik eden kırdan kente göç ile kent yaşamında özel alan-kamusal alan ayrımı ortaya çıkmış ve bu ayrım, kadınların üzerinde yeni bir kontrol mekanizması oluşturmuştur. Bu süreçte ilkin kadınlar ve onların çocukları ağır şartlar altında istihdam edilmiş sonrasında ise bu bireyler, sermayenin ve erkek işgücünün niceliğinin artışı ile evlere gönderilmişlerdir. Böylece kamusal alan erkeklere tahsis edilirken kadınların çok büyük bir kısmı ev işlerini ve çocuk bakımını yerine getirmek üzere özel alan ile sınırlandırılmışlardır (Finley, 1986, ss. 1118-1119).

Erkeğe kamusal alanda evin geçimini sağlama kadına ise ev işleri ve çocuk bakımı rollerini atfeden bu evcimenlik kültü ya da ayrı dünyalar ideolojisi, bazı toplumlarda diğer ideolojilerle harmanlanarak günümüze değin ulaşmış olmakla birlikte büyük ölçüde aşınmaya da uğramıştır. Evcimenlik kültünün iki ayağından biri olan ev işleri, teknolojik gelişmeler ve ailenin artan gelir seviyesi doğrultusunda zaman içerisinde önemini yitirirken diğer ayağını oluşturan çocuk bakımı ise kadınların doğrudan biyolojik yetisi olan anneliğe iliştirilerek varlığını korumaktadır.

Çocuk bakımının anne tarafından yapılması gerektiği düşüncesini temel alarak gelişen annelik ideolojileri, farklı toplumlarda kadınların özel alan ile sınırlandııımasına ve cinsiyete dayalı işbölümünün devamlılığına hizmet etmiştir. Annelik ideolojileri, toplumun anneliğe atfettiği değeri, annelik kurumundan beklentilerini, kültürel kodların annelik üzerindeki tezahürünü ve dolayısıyla annelik faaliyetlerini ve bu merkez etrafında geliştirilen aile ilişkilerini şekillendiren sistemli düşünce tarzını ifade etmektedir (Garey, 2008; McGlynn, 2000, s. 30). Esasen annelik ideolojileri toplumun temel yapı taşı kabul edilen aile ideolojisi ile birbirini tamamlamaktadır. Zira aile ideolojisi, erkeğin baba ve eş olarak hane reisi olduğu anne ve çocuklardan oluşan çekirdek aileyi işaret ederken annelik ideolojileri, bu ailenin devamlıı̆ı̆ını sağlamaktadır. Ailenin devamlılı̆ı, kadının ömrünü eşine ve çocuklarına adaması halinde mümkün görülmekte ve bu adanmışlğın sekteye ya da kesintiye uğraması ise bu ideolojiler nezdinde sapma olarak değerlendirilmektedir. 
Karşıt bir görüş olarak Rich (1977), anneliğin, yaşam sürecinde bir kesit olduğunu bu nedenle kadınların tüm yaşamının bu kesitten ibaret kabul edilmemesi gerektiğini ve bu ideolojilerin kadını kadın olmaktan önce anne olarak değerlendirdiğini belirtmektedir. Bir bebeğin doğumuna kadar geçen süre ve annesinin bakımına muhtaç olduğu süre, insan ömründe belirli bir süreye karşılık gelmektedir. Buna rağmen kadınların anneliklerinden önce ve sonra da tüm tutum ve davranışları, annelik ideolojileri doğrultusunda değerlendirmeye tabi tutulmaktadır. Diğer bir deyişle annelik, bu ideolojiler tarafından kadının yapmış olduğu sıradan faaliyetlerden ziyade kimliğini belirleyen ve bu kimliğin sağlamasını yapan bir olgu olarak kabul görmektedir (Walby, 1990, s. 106).

Geçmişten günümüze değin annelik kimliğini belirleyen birçok ideolojik yaklaşım ortaya çıkmıştır ve bunların bir kısmı birbirini destekler nitelikte olmasına rağmen bir kısmı ise tezatlık içindedir. Diğer taraftan her toplumda bu ideolojilerin biri ya da birkaçı daha fazla etki alanına sahip olarak daha fazla kabul görmüşler ve o toplumda hâkim annelik ideolojisi haline gelerek anne olan ya da olmayan tüm kadınları kapsamışlardır (Garey, 2008). Bunun anlamı ise anneliğin deneyimlenme şeklinin bu ideolojiler tarafından belirlenmesi ve bu ideolojiler doğrultusunda yaşanması beklentisidir.

Annelik ideolojilerinin genel olarak benzer nitelikleri olmasına rağmen tarihsel ve toplumsal olarak incelendiğinde bir toplumda yalnızca tek bir ideolojinin tüm zamanlarda kabul gördüğünü ileri sürmek mümkün değildir. Lupton $(2000$, s. 53) da farklı toplumlarda, farklı dönemlerde hâkim olmuş ideolojilerin zamanla geçerliliklerini yitirebileceğini, dirençle karşılaşabileceğini ya da kaymalara, aşınmalara uğrayabileceğini ve hatta tamamıyla terkedileceğini belirtmiştir. Ancak bir toplumda geçerliliğini yitirmiş bir annelik ideolojisi, diğer bir toplumda hâkim hale gelebilir.

Annelik ideolojileri, bu özellikleri ve çeşitliliği nedeniyle daha yakından incelenerek bu ideolojilerin farklı dönemlerde, toplum üzerindeki tezahürlerinin 2000'li yıllardan itibaren geçirdikleri dönüşüm ve bu dönüşümün çalışma hayatına etkileri, $\mathrm{OECD}$ verileri incelenerek değerlendirmeye tabi tutulacaktır.

\section{Ataerkil İdeoloji, Teknoloji İdeolojisi ve Kapitalizm İdeolojisi}

Annelik ideolojisini şekillendiren üç ideolojiden bahsedilmektedir; ataerkil ideoloji, teknoloji ideolojisi ve kapitalizm ideolojisidir. Rothman (1994) bu ideolojilerin annelik ideolojisi üzerinde önemli etkilere sahip olmasından dolayı bunları, erkeklerin kadınlar üzerinde egemen olmasını güçlendirmeye, kamusal alan ve özel alan arasındaki ayrımı belirginleştirmeye hizmet etmekte olan düşünce tarzları olarak tanımlamıştır.

Bu ideolojilerin başında yer alan anneliğin ataerkil ideolojisine göre kadınların kendilerini yalnızca anneliğe adamaları gerekmekte ve farklı alanlarda varlık göstermeleri kabul görmemektedir (Glenn, 1994). Ataerkil ideoloji, kadın ve erkeğin toplumsal alanda yerlerini belirleyerek kadınları ev içindeki işlerle sınırlandırmış ve böylece annelik ideolojilerine dayanak oluşturmuştur.

Temel birimini ailenin oluşturduğu ataerkil ideoloji, 2500 yıllık bir geçmişe sahiptir ve birçok araştırmacı, bu ideolojinin kadın ve erkek arasındaki biyolojik farklııklara yaptığı vurgu ile toplumun 
değer yargılarını, kurallarını ve davranış kalıplarını yeniden üreterek erkeklerin üstünlüğünü pekiştirdiğini savunmuştur (Lerner, 1986, ss. 212-217; Green, 2010, s. 970).

Rothman (1994, ss. 140-143) da erkeğin kadına göre daha üstün tutulduğu görüşüne katılmanın yanı sıra ataerkil ideolojinin yalnızca kadın ve erkek arasındaki ilişkileri değil aynı zamanda anne ve çocukları arasındaki ilişkileri de belirlediğini ifade etmiştir. Zira ataerkil bir düzende bir kadının anneliği, bir erkeğin soyunun devamı olacak çocukları dünyaya getirmesi anlamına gelmektedir. $\mathrm{Bu}$ nedenle ataerkilliğin devamı da erkeğin kadınların hayatları, annelikleri ve bedenleri üzerinde kurdukları denetimin devamlılı̆̆ ile söz konusu olacaktır.

Kadın bedeni üzerinde erkeğin kurduğu denetim, kapitalist sistem doğrultusunda ortaya çıkan özel-kamusal alan ayrımı ile güç kazanmıştır ve bu birliktelikten doğan ataerkil kapitalizm, annelik ideolojileri üzerinde belirleyici olmuştur. Rothman (1989), kadının erkeğin mülkiyetinde kabul edilmesi ve erkeğin soyunun devamlılı̆ına hizmet eden bir üretim aracı olarak görülmesi şeklindeki bu durumu, kadın bedenini “çiçek saksısı"na benzeterek simgeleştirmiştir. Zira erkekler tüm güçleriyle kapitalizme hizmet ederken kadınların payına, erkeklerin biyolojik açıdan gücünün yetmediği tek durum olan kapitalist sisteme hizmet etmek üzere yeni neferler dünyaya getirmek ve onları yetiştirmek düşmüştür.

Bu doğrultuda kapitalizm ideolojisinin annelik ideolojisi üzerindeki tezahürü, anneliği emek; dünyaya getirdiği çocuğu ise o emeğin ürünü olarak ele almak biçiminde gerçekleşmiştir. Tıpkı emek piyasasında yapılan işlerin ve elde edilen ürünlerin birbirinden farklı değerlere sahip olması gibi anneliğin değeri de çocuğun değeri ve niteliği ile ölçülmektedir (Rothman 1994, s. 149). Kapitalizm ideolojisi, her zaman kârlı olana yönelmektedir ve kapitalizme göre kârlı olan erkeklerin emeklerini çalışma hayatında kullanmalarıdır. Kadınlar ise -ücretsiz- emeklerini, ev işlerine ve çocuk bakım faaliyetlerine vakfetmelidir. Öyle ki sanayileşmenin ilk zamanlarından bu yana her geçen gün kadınların emek piyasasına daha fazla oranda dâhil olması bile onları, ev işleri ve annelik faaliyetlerinden muaf kılmamıştır. Bu nedenle kapitalizm ideolojisinin annelik ideolojileri üzerinde yarattığı etki yadsınamayacak ölçüdedir.

Annelik ideolojisini ataerkil ideoloji ve kapitalizm ideolojisi ile birlikte destekleyen ve besleyen diğer bir ideoloji ise teknoloji ideolojisidir. Bu ideoloji, teknoloji ve makineler ile insanların benzer bir biçimde değerlendirmeye tabi tutulmasını içermektedir. Rothman (1994)'a göre, teknoloji ideolojisinin annelik üzerindeki tezahürü, annelik görevlerinin tıpkı bir makine ya da robot gibi sistematik, planlı ve programlı bir biçimde yerine getirilmesi gerekliliğini işaret eden bir nevi "yapılacaklar listesi"dir ( s. 144). Belirtilen yapılacaklar listesi, gebe kalınacak zamanın belirlenmesinden itibaren bebeğin anne karnındaki tüm gelişiminin izlenmesi, bu süreçte annenin yapması ve yapmaması gerekenlerin belirlenmesi, doğumun ne zaman ve ne şekilde gerçekleşeceğine karar verilmesi ve doğumdan sonraki tüm süreçlerde çocuğun anne tarafından beslenmesi, bakılması, korunması, büyütülmesi gibi tüm faaliyetlerden annenin sorumlu tutulmasını kapsamaktadır. Bu liste sistematik bir biçimde izlendiğinde kadınlar iyi birer anne olarak kabul edilmektedir. 


\section{3. Özcü, Doğal ve Tıbbi Ideolojiler}

Teknoloji ideolojisinde bedenin bir makine olarak kabul edilmesi şeklindeki söylem, anneliğe dair tıbbi ve özcü ideolojilerde de yer bulmaktadır. Teknolojik gelişmelerin henüz hiç yaşanmadığı dönemlerde ve hatta günümüzde bu teknolojilerin ulaşamadığı yerlerde herhangi bir tıbbi kontrole tabi tutulmaksızın tamamen doğal bir biçimde seyreden ve gerçekleşen annelik süreci artık her geçen gün müthiş bir hızla gelişen teknoloji aracılığıyla takip edilmektedir. Biyolojik olması nedeniyle doğal bir durum olarak kabul edilen annelik, bu ideolojiler çerçevesinde profesyonel bir yapıya oturtularak ele alınmaktadır. Green (2010) da doğum kontrol yöntemlerinin, üreme teknolojilerinin, gebeliğin tüm anlarının izlenebilirliğinin, doğumun gerçekleşeceği zamanın belirlenebilmesinin ve bunun profesyonel uzmanlarca yapılmasının bedeni bir makine olarak ele alan bu teknoloji ideolojisiyle tutarlı gelişmeler olduğunu belirtmiştir (s. 971).

Tıbbi ideoloji, doğum ve annelik süreçlerinde tıbbi uzman desteği alınması ve tıbbi teknolojilerden yararlanılması gerektirdiğini iddia etmektedir. Bu söyleme göre iyi bir anne olmak için kadınların hamilelik döneminde, doğum esnasında ve diğer annelik faaliyetlerinde erkek uzmanlardan destek almaları gerekmektedir (Miller, 2007, s. 338). Örneğin üreme teknolojilerinde kat edilen aşama, her kadının anne olma kapasitesine ve içgüdüsüne sahip olduğunun varsayılmasına dayanmaktadır. Ancak anneliğin özcü ve doğal ideolojilerinin savunduğu kadınların biyolojik özellikleri nedeniyle ve doğal olarak anne oldukları görüşü, kadın hastalıkları ve doğum, çocuk hastalıkları, psikoloji gibi alanlardaki uzmanların ağılıklı olarak erkeklerden oluşması ile tezatlık göstermektedir. Kadınlara ait görülen ve adeta mucizevi sayılan doğum yapabilme yetisi, anneliğin doğal ideolojisine dayanak oluştururken bu yetinin gerçekleşmesi için tıp alanlarında uzmanlaşmış erkeklere başvurulması çelişkili bir durum olarak kabul edilmiştir.

Anneliğin özcü ve doğal ideolojilerine göre kadınların biyolojik özellikleri nedeniyle anne olması kaçınılmazdır. Zira annelik, içgüdüsel bir olgudur ve evrensel olarak kadınların tecrübe ettiği değişmez bir gerçektir (Miller, 2005, s. 55). Bu ideolojiler, anneliğin kadınlığın özünde bulunduğunu, anne olmanın doğal getirisi olarak çocuk bakım faaliyetlerini de annenin üstlenmesi gerektiğini ve kadınların çocuk bakım faaliyetlerine içgüdüsel olarak yatkın ve bu becerilere sahip olarak doğduklarını savunmaktadır. Özcü söylem doğrultusunda kadınlar, genetik özellikleri ve biyolojik yapıları nedeniyle çocuk bakımından muaf tutulamazlar (Coulter, 2010, s. 358). Özcülük, kadın olmayı somut hale getiren olgunun annelik olduğu varsayımına dayanmaktadır (DiQuinzio, 1999, s. 89). Diğer bir deyişle kadınların dünyaya anne olmak ve annelik ile ilgili tüm faaliyetleri yerine getirmek üzere geldiği anlayışı bu ideolojinin temelinde yer almaktadır.

Bu düşünce sistemine göre çocuk bakım faaliyetleri çocuğun yalnızca fiziksel ihtiyaçları ile sınırIı kalmayarak çocuğa gösterilmesi gereken sevgi ve bağ|lığı da kapsamaktadır ve çocuğu dünyaya getiren kişi olan anneden başka bu emeği verebilecek bir başkası kabul görmemektedir. Bu ideolojiye getirilen eleştirilerin başında anneliğin doğrudan doğumla ilişkilendirilmesi ve evlat edinen ya da bir erkeğin başka bir kadından olan çocuğuna annelik yapan ya da çocuk sahibi olmamayı tercih eden kadınların durumunun sapma olarak değerlendirmesi yer almaktadır. Örneğin masallarda 
Eda KILIÇ

üvey annelerin kötü kalpli, zalim, acımasız olarak tasvir edilmesi (Dainton, 1993), yine bizim kültürümüzde besleme tabiriyle evlatlık edinilen çocuklara kötü muamelede bulunulması bu görüşü destekler niteliktedir.

Özcü ve doğal ideolojiler, birçok toplumda büyük ölçüde destek görmüş olmakla birlikte zaman içerisinde annelik ve kadınlığın birbirinden farklı iki olgu olduğu ve bir kadının kadınlığının anlam kazanabilmesi için çocuk sahibi olmaya ihtiyaç duymadığı düşüncesi gelişmiştir. Günümüzde annelik sorumluluğunun yükünü almak istemeyerek çocuk sahibi olmamayı tercih eden kadınların yanı sıra kadınlığın ve anneliğin farklı kimlikler olduğunu kabul ederek anneliği yaşayanların da sayısı azımsanamayacak orandadır (Badinter, 2011, s. 121).

Annelik ideolojileri, çocuğu dünyaya getiren cinsin kadın olması nedeniyle çocuk bakımını doğrudan kadına atfederek onun evde kalması ve çocukları ile ilgilenmesi gerekliliğini güçlendirmiştir. Böylece ataerkil ideoloji ve kapitalizm ideolojisini desteklemiştir. Özcü ideolojilere göre anne olmak için dünyaya gelen ancak anne olmamayı tercih eden kadınlar ya da çocuğunun bakımını diğer insanlara devreden ya da onlarla paylaşan kadınlar başarısız olmaktadırlar. Bu annelik mitleri, kadınlar tarafından ancak büyük bir direnç gösterilmesi halinde aşılabilmektedir.

Yukarıda değinilen ataerkil, kapitalist, teknolojik, özcü ve tıbbi annelik ideolojileri, birbirini destekleyerek zaman içerisinde yoğun annelik ideolojisinin oluşmasını ve bu ideolojinin hâkim ideoloji haline gelmesini sağlamıştır.

\section{Yoğun Annelik İdeolojisi}

Yoğun annelik ideolojisi, toplum tarafından kabul gören annelik etme şeklinin modernize edilmiş hali olarak tanımlanmaktadır (Hays, 1996, s. X). Bu ideolojinin de özcü annelik ideolojisi gibi ataerkil ideolojinin kadınlar üzerinde denetim kurmasına destek olduğu savunulmuştur. Birçok farklı toplumda ve sınıfta kadınlar tarafından içselleştiren bu ideoloji, hâkim ideoloji haline gelerek birçok feminist araştırmacının (Douglas ve Michaels, 2004; Hallstein, 2010; Johnston ve Swanson, 2006; O’Reilly, 2007) ilgi alanını oluşturmuştur. Anneler, bu ideoloji çerçevesinde annelik faaliyetlerini gerçekleştirmeye çalışırken toplum tarafından yine bu doğrultuda değerlendirmeye tabi tutularak eleştirilmekte, kabul görmekte ya da reddedilmektedir.

Amerika'da yapılan bir araştırmaya göre annelerin yoğun annelik ideolojisine uygun inançlara sahip oldukları ve çocuk sahibi olmayı kutsal, iyi gibi olumlu kavramlarla tanımladıkları ortaya çıkmıştır (Hays, 1996, s. 41). Teknolojik gelişmeler doğrultusunda gerek doğum gerek hamilelik süreçlerinde gerekse çocuk yetiştirme tekniklerinde gerçekleşen gelişmelere duyulan güven, bu inançları güçlendirmektedir. Tıp ve psikoloji alanlarında uzmanlaşmış kişilerden alınan destek ve rehberlik, kadınların yoğun annelik sürecini layıkıyla yerine getireceklerine dair güven duygusunu tesis etmekle birlikte kadınların doğum ve çocuk bakımı süreçleri üzerindeki kontrollerini yitirmeleri anlamını taşımaktadır. 
Özellikle çocuk yetiştirme teknikleri üzerinde geniş etki alanına sahip en önemli psikolojik kuramlardan biri Bowlby'nin (1969) bağlanma kuramıdır. Bu kurama göre normal ve sağlıklı bir gelişimin temelinde anne ve çocuk arasında kurulan bağın önemi büyüktür. Bir kadının bebeği ile sağlıklı ve güvenli bir bağlanma gerçekleştirebilmesi için ev dışında yapacağı tüm düzenli faaliyetlerden (çalışma hayatı, eğitim, hobiler) feragat etmesi gerekmektedir. Bir annenin iyi anne olarak nitelendirilmesi bu fedakârlık koşuluyla mümkün görülmektedir.

Bağlanma teorisi, geniş kitleler üzerinde yarattığı etkiye rağmen pek çok eleştirinin odağında olmuştur. Bu teorinin özellikle üç unsuru en fazla eleştiriyi almaktadır. Bu unsurlardan ilki, çocuğun uzun sürelerle ve sürekli emzirilmesi gerekliliği, ikincisi çocuğun ebeveynleri ile aynı odada ya da aynı yatakta uyumasının önerilmesi, sonuncusu ise anne ve çocuk arasında oluşması gereken duygusal bağın çocuğun annenin bedenine iliştirildiği bir takım araç gereçlerle somutlaştırılmasıdır (Pickert, 2012, s. 34). Çocuğun anneye bağlanmasını sağlamaya çalışırken bağımlı hale getirilmesi hem psikolojik gelişimi hem de annenin çalışma hayatı gibi kendisini geliştireceği diğer faaliyetleri üzerinde olumsuz etkilere yol açacaktır.

Kısacası yoğun annelik; merkezde çocuğun bulunduğu, anneliğin duygusal olarak içselleştirildiği, uzman profesyonellerden destek alındığı, yüksek maliyetli ve yoğun emek gerektiren bir annelik şeklidir (Hays, 1996, s. 8). Bu ideoloji, kadınlardan tam anlamıyla bir adanmışlık beklemektedir. Anne, çocuğun gelişiminden sorumlu tek kişi olarak görülmektedir. Bu nedenle bu sorumluluğu yerine getirirken kendisinden bu ideolojinin sunduğu yöntemleri uygulaması ve kendini gerçekleştirmek için yalnızca anneliği seçmesi beklenmektedir.

Bu ideoloji daha önce değinilen ideolojilerin bir araya gelmesi ile oluşmuştur. Çocukların ihtiyaçlarının yalnızca onları dünyaya getiren anneleri tarafından karşılanması gerekliliği özcü annelik ideolojisinin etkisini işaret ederken uzman profesyonellerden yardım almak tıbbi ideolojinin etkisini yansıtmaktadır. Ataerkil ideolojinin çıkış noktası olan kadının yerinin evi ve çocuklarının yanı olduğu düşüncesi ise yoğun annelik ideolojisinde kadınların tüm zamanını ve enerjisini çocuklarını yetiştirmeye harcamaları gerekliliği ile karşılık bulmuştur.

Bir kadının hem tam zamanlı istihdama katılması hem de yoğun annelik ideolojisinin beklentilerini karşılayacak şekilde annelik faaliyetlerini yerine getirmesi mümkün olamayacağı için anneler, elde edecekleri gelirden, mesleki olanaklardan ve kişisel gelişim ve tatminden fedakârlık etmek zorunda kalacaklardır (Hays, 1996, s. 8). Medyanın da yoğun annelik ideolojisini birçok mecrada parlatması ve iyi annelik kriterlerini toplumun tüm kesimlerine ulaştırması bu ideolojinin yaygınlaşması üzerinde etkili olmuştur.

Annenin asıl ve tek işinin çocuğu ile ilgilenmesi olduğu kanısı, onu sosyal hayattan tamamen yalıtmaktadır. Bu ideoloji doğrultusunda kadının çalışma hayatı yerine anneliği ve evde kalmayı tercih etmesi ailenin tek geçim sağlayıcısı olan erkeğin belirli bir seviyede gelir elde etmesi halinde mümkün olacaktır (Dillaway ve Paré, 2008, s. 461). Erkeğin gelirinin evin geçimini sağlamaya yeterli gelmediği durumlarda ise kadının istihdama katılması kişisel bir tercih olmaktan ziyade bir zorunluluk olarak değerlendirilmektedir. Bu durumun zorunluluk olarak kabul edilmesine rağmen çalışma 
hayatının koşulları, kadının yoğun annelik ideallerinden uzak düşmesine diğer bir deyişle iyi anne kategorisinin dışına çıkmasına yol açmaktadır (Lewis, 1991, s. 195). Kısacası yoğun annelik ideolojisine uygun bir annelik tarzı, kadının özel alanda çocukları ile birlikte kaldığı, kendisini tamamıyla buna adadığı ve çalışma hayatının dışında kaldığı bir annelik tarzıdır.

Bahsi geçen tüm bu ideolojiler, anneliğin anneliği deneyimleyen kişiye özgü olma yönünü göz ardı ederek tüm annelerin benzer karar alma mekanizmalarına, deneyimlere, tercihlere ve benzer ekonomik imkânlara sahip olduklarını varsaymışlardır. Oysa toplumda bu ideolojiler tarafından normal kabul edilen annelik deneyimleri dışında da birçok annelik deneyimi mevcuttur; yalnız anneler, yoksul anneler ya da çalışan anneler bu ideolojiler için atipik örnekler olup kapsam dışında bırakılmışlardır. Green (2010, s. 971), bu ideolojilerin ancak anneliğin makul bir yaşta (20-25), evlilik çatısı altında gerçekleştiği, erkeğin tek geçim sağlayıcı olarak çalıştığı ve kadının ev işleri ve çocuk bakım faaliyetleri ile ilgilendiği toplumsal kesimlerde hâkim konuma ulaştığını ileri sürmektedir.

Annelik, kadınların bireysel tercihleri ya da kendi hayatları ile ilgili almış oldukları kararlar doğrultusunda gerçekleşiyor olsa da toplumun ortak ilgi alanını oluşturmaktadır. Hâkim annelik ideolojilerinin yargıları, tutumları ve kalıpları, yalnızca bu ideolojilerin etkisi altında kalan kadınları değil aynı zamanda annelik tercihleri bu ideolojinin dışında gerçekleşen (çocuksuzluk, çalışan annelik, yalnız annelik vb.) kadınları da değerlendirmeye tabi tutmakta ve etiketlemektedir. Bu durum, kadınları, kendi hayatlarının kontrolünü sağlamak açısından bir hayli zorlamaktadır (Haynes, 2008, s. 627).

Dayatılan bu tutumlar, fikirler, normlar ve davranış biçimlerini içselleştirdikleri için ya da toplum tarafından dışlanmamak, yaftalanmamak ve eleştirilmemek için bunlara uyum sağlama zorunluluğu hisseden kadınlar, çalışma hayatı ya da diğer sosyal faaliyetlerinden fedakârlık ederken bireysel gelişimlerini, tatminlerini ve mutluluklarını da bir yana bırakabilmektedirler.

Özellikle son yirmi yılda çalışma hayatına katılan kadınların sayısında görülen artışın yanı sıra çalışan anneler de artmaktadır. Anneliğe adanmış bir hayat yerine ne annelikten ne de çalışma hayatından vazgeçen kadınların yoğun annelik ideolojisini aşınmaya uğratması ile annelik ideolojisi, yeni bir dengeye doğru ilerlemeye başlamıştır. Bu yeni denge, özellikle son yirmi yılda dünya üzerinde birçok ülkeye beraberinde yasal düzenlemeleri ve uygulama alanlarını getiren çalışan anne ideolojisidir.

\section{5. Çalışan Anne İdeolojisi}

On sekizinci yüzyıl sonlarından itibaren ev ile işyerinin birbirinden ayrılması şeklinde gerçekleşen kamusal ve özel alan ayrımı, toplumsal cinsiyet ilişkilerini de biçimlendirmiş ve özellikle orta sınıftaki kadınları, evin dışında bir hayata uygun olmadıkları kabulü ile çalışma hayatının dışında, erkekleri ise ait oldukları düşünülen çalışma hayatında konumlandırarak ayrı dünyalar ideolojisini

diğer bir tabirle evcimenlik kültünü baskın hale getirmiştir (Hall, 1992). Bu ideoloji doğrultusunda 
erkekler, istihdamda yer alırken yerine getirdikleri iş ile kadınlar ise ev içerisinde sağladıkları bakım emeği ve diğer ev işleri ile değerlendirmeye tabi tutulmuştur.

1950'lerden itibaren kadınların da erkeklerle benzer eğitim düzeylerine ulaşmaları ve birçok meslekte kendilerine yer edinebilmeleri ile kadınların işgücüne katılım oranları yükselmeye başlamıştır (Blau ve Kahn, 2007; Goldin, 2006; Goldin ve Katz, 2002).

Ancak çalışma hayatına katılan kadınların evlendiklerinde ya da en iyi ihtimalle anne olduklarında çalışma hayatına uzun sürelerle ara vermeleri ya da çalışma hayatının tamamen dışına çıkmaları hâkim annelik ideolojileri ile tutarlı bir biçimde annelik ve çalışma hayatının bir arada yürütülmesini olanak dışı bırakmıştır.

1970'lere gelindiğinde özellikle doğum kontrol hapının kullanımı ile kadınlar hem kendi bedenleri hem de hayatları üzerinde kontrol sahibi olabilmiş, annelik zamanını belirleyebilme özgürlüğü kazanmışlardır (Goldin, 2006). Sanayileşmiş ülkelerde kadınların özellikle de annelerin işgücüne katılım oranlarında artış yaşanmıştır. Diğer taraftan bu süreçte anneler, çocuksuz kadınlardan daha az çalışmak -çocuk bakım faaliyetleri nedeniyle yarı zamanlı çalışmaya yönelme- dolayısıyla daha az kazanmak gibi olumsuz sonuçlar yaşamıştır (Blundell, Bozio ve Laroque, 2011; Joshi, Paci ve Waldfogel, 1999). Tam zamanlı çalışan annelerin dahi çalışma hayatında yeterli performans göstermedikleri ve örgütsel bağılıklarının zayıf olduğu şeklinde önyargılar ile karşı karşıya kaldığı göz önünde bulundurulduğunda yarı zamanlı işlerde çalışan annelerin yaşadığı sorunlar azımsanamayacak boyuttadır. Tam zamanlı ya da yarı zamanlı çalışan kadınların anne olmaları halinde çalışma yaşamında karşı karşıya kaldıkları ve annelik ile çalışmanın bir arada yürütülmesinin yarattığı zorluklar nedeniyle istihdam oranlarının düştüğü düşünülmektedir (Lundborg, Plug ve Rasmussen, 2014). 1970’lerden önce kadın çalışanların büyük bir kısmı annelik sonucunda çalışma hayatından çekilmeyi ya da çalışmaya uzun sürelerle ara vermeyi tercih etmiş̧ir. Son yıllarda bu seçenek hala varlığını korumakla birlikte bu seçimi yapan annelerin sayısında önemli düşüşler yaşanmıştır. Kadınların anneliği çalışma hayatına tercih etmek yerine çalışma hayatı ile bir arada sürdürme eğilimindeki artış, yapılan araştırmalar ve istatistiksel veriler ile de ortaya konmaktadır. Örneğin, Amerika Birleşik Devletleri'nde yapılan bir araştırma çocuk sahibi olmanın kısa vadede istihdamı azaltmasına rağmen uzun vadede istihdama olumsuz bir etkisi olmadığını ortaya koymuştur (Cristia, 2008).

Şekil 1'de OECD verileri incelendiğinde, kadınların genellikle çocuk sahibi oldukları yaşlarda istihdama katıımının OECD ülkelerinde özellikle 1960'lardan itibaren düzenli artış eğilimine girdiği ve bazı ülkelerde oldukça yüksek seviyelerde gerçekleştiği görülmektedir (OECD, 2017) 


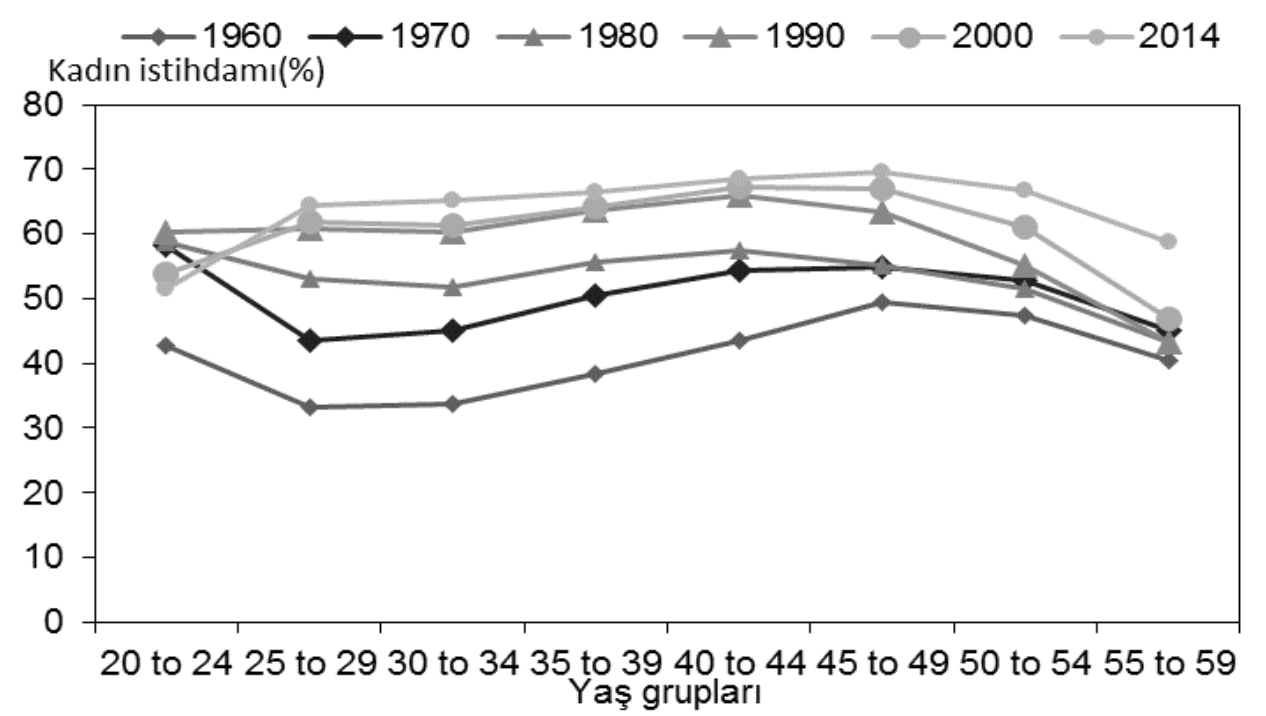

Şekil 1. OECD Ülkelerinde Kadınların Yaş-İstihdam Profilleri, (1960-2014 Yılları Arası)

Kaynak: OECD (2017)

20-24 yaş arası kadınların işgücüne katılımı 1960’larda \%42 seviyelerinde iken özellikle 1970'lerden 2000'li yıllara kadar \% 60 seviyesinde seyretmiş kadınların eğitim seviyelerinde artış yaşanması nedeniyle 2000 'li yıllardan günümüze kadar olan süreçte $\% 51^{\prime}$ e düşmüştür. 2000'li yıllarda ise kadınların işgücüne katılım oranlarındaki değişimler belirgin şekilde görülmektedir. 1990'lı yıllara değin kadınların ilk doğumunu gerçekleştirebileceği yaşlarda istihdam seviyelerinde düşüş gözlenirken sonraki yaşlarda yeniden artış eğilimi ortaya çıkmıştır. 2014'te ise 25 yaşından itibaren istihdam seviyeleri \% 60'larda seyretmekte yaş ile birlikte çok küçük oranlarda artış göstermektedir. Doğurganlık döneminde istihdama katııımın azalmak bir yana artması artık daha fazla kadının annelik ile çalışmayı bir arada yürütmeyi tercih ettiğinin bir göstergesi olarak değerlendirilebilir. Şekil 1'deki kadınların yaşa göre istihdam göstergeleri, OECD ülkelerinin ortalaması açısından anlamlı olup ülkeler arasında ise farklııklar göstermektedir. Bu farklılıklar, gerek tam ve yarı zamanlı çalışma tercihleri gerekse istihdam oranları açısından ortaya çıkmaktadır. Tablo 1'de 2014 ve sonrası dönemde 0-14 yaş arası ve en az bir çocuk sahibi kadınların tam ve yarı zamanlı çalışma durumları ve istihdam oranları verilmektedir.

Tablo 1'de gösterildiği üzere çalışma hayatı ile anneliği bir arada yürütmeyi tercih eden kadınların oranı OECD ortalamasına göre $\% 66,2$, AB ortalamasına göre ise $\% 68,2$ 'dir. En yüksek istih- 
dam oranına sahip ülke İsveç (\% 83,1), sırasıyla İsveç'i takip eden ülkeler ise Danimarka, Slovenya, İsviçre ve Litvanya'dır. Meksika \% 44,8, Kosta Rika \% 51,5, Yunanistan \% 52,2 ile OECD ülkeleri arasında alt sıralarda yer alırken, Türkiye \% 30 oranla kadın istihdam oranının en düşük olduğu ülkelerden biridir. $O E C D$ ve $A B$ ülkelerinde genel eğilim tam zamanlı çalışmadan yana olmakla birlikte tam zamanlı çalışan annelerin oranının yarı zamanlı çalışan annelerden daha az olduğu ülkeler ise Avusturya, Hollanda, Almanya iken Türkiye'de ise çalışan annelerin yaklaşık üçte biri yarı zamanlı çalışmayı tercih etmektedir. Diğer bir deyişle Avusturya, Hollanda, Almanya gibi ülkelerde çalışan anneler, tercihlerini yarı zamanlı çalışmadan yana kullanmaktadır. Yarı zamanlı çalışma, annelik ve istihdamın dengede tutulmasında en çok tercih edilen çalışma biçimlerinden biridir. Bazı ülkelerde yarı zamanlı çalışan annelerin oranı oldukça düşük seviyelerde kalmış (Danimarka, Slovenya, Litvanya vb.), bazı ülkelerde ise tam zamanlı çalışan annelerin oranları ile neredeyse aynı seviyede seyretmiştir (Birleşik Krallık, Yeni Zelanda, İrlanda). Bu farklı eğilimlerin temelinde ülkelerin çalışma kültürlerine ve çalışma hayatına dair özelliklerin çeşitliliği yatmakla birlikte kaliteli ve düşük maliyetli çocuk bakım hizmetlerinin yaygınlaşma oranları da yer almaktadır. Özellikle 1980'lere kadar birçok ülkede çocuk bakım hizmetlerinin yaygın olmaması verilen hizmetlerin ise oldukça maliyetli olması bu hizmetlerin alternatif bir çözüm olarak kabul edilmesinin önüne geçmiştir. Bu nedenle annelik ve çalışma hayatını uyumlu hale getirme arzusu çoğunlukla yarı zamanlı işlerin tercih edilmesi ile sağlanmaya çalışımıştır (Fagan ve Norman, 2012; Joshi, Macran ve Dex, 1996).

Tablo 1. Yarı Zamanlı-Tam Zamanlı Çalışma Durumlarına Göre 0-14 Yaş Arası En Az Bir Çocuk Sahibi 15-64 Yaş Arası Kadınların İstihdam Oranları (2014 ya da Elde Edilen En Son Verilere Göre)

\begin{tabular}{|c|c|c|c|c|c|c|c|c|c|}
\hline & $\begin{array}{l}\text { ist. } \\
\text { oranı }\end{array}$ & $\begin{array}{l}\text { Tam } \\
\text { zam. } \\
\text { Ist. }\end{array}$ & $\begin{array}{l}\text { Yarı } \\
\text { zam. } \\
\text { Ist. }\end{array}$ & Diğer & & $\begin{array}{l}\text { Ist. } \\
\text { oranı }\end{array}$ & $\begin{array}{l}\text { Tam } \\
\text { zam. } \\
\text { ist. }\end{array}$ & $\begin{array}{l}\text { Yarı } \\
\text { zam. } \\
\text { Ist. }\end{array}$ & Diğer \\
\hline İsveç & 83,1 & & & & Birleşik Krallık & 67,1 & 33,0 & 33,3 & 0,8 \\
\hline Danimarka & 82,0 & 72,2 & 9,6 & 0,1 & OECD-31 ort. & 66,2 & & & \\
\hline Slovenya & 79,1 & 72,3 & 6,8 & 0,0 & Romanya & 65,8 & 60,6 & 5,1 & 0,0 \\
\hline İsviçre & 77,5 & & & & $A B D$ & 65,7 & 53,1 & 12,4 & 0,3 \\
\hline Litvanya & 75,8 & 66,5 & 7,8 & 1,4 & Estonya & 65,5 & 57,7 & 7,7 & 0,0 \\
\hline Avusturya & 75,7 & 35,3 & 40,5 & 0,0 & Bulgaristan & 65,3 & 61,3 & 1,6 & 2,4 \\
\hline Portekiz & 75,7 & 68,4 & 5,4 & 1,9 & Japonya & 63,2 & & & \\
\hline Hollanda & 74,8 & 24,0 & 50,8 & 0,0 & Yeni Zelanda & 63,2 & 36,0 & 27,2 & \\
\hline Lüksemburg & 74,8 & 48,6 & 23,9 & 2,3 & Avustralya & 62,9 & & & \\
\hline Kanada & 73,7 & 56,8 & 16,8 & & Çek Cum. & 61,6 & 56,2 & 5,4 & 0,0 \\
\hline Finlandiya & 73,6 & 63,6 & 7,2 & 2,8 & İrlanda & 60,2 & 35,2 & 24,4 & 0,6 \\
\hline Belçika & 72,4 & 49,9 & 22,1 & 0,3 & İspanya & 59,5 & 43,2 & 14,9 & 1,4 \\
\hline Rusya & 72,3 & 61,2 & 11,1 & & Macaristan & 58,1 & 52,0 & 4,2 & 1,9 \\
\hline Fransa & 72,2 & 55,7 & 15,5 & 1,0 & Malta & 56,8 & 40,4 & 16,2 & 0,2 \\
\hline İsrail & 72,1 & & & & Slovakya & 56,6 & 50,3 & 4,0 & 2,3 \\
\hline
\end{tabular}


Eda KILIÇ

\begin{tabular}{llllllllll}
\hline Litvanya & 70,1 & 63,4 & 6,2 & 0,5 & Italya & 55,3 & 34,8 & 20,4 & 0,1 \\
Kıbrıs & 69,6 & 59,3 & 10,2 & 0,1 & Şili & 54,9 & 41,3 & 13,2 & 0,4 \\
Hırvatistan & 69,2 & 66,3 & 2,9 & 0,0 & Yunanistan & 52,2 & 43,1 & 9,2 & 0,0 \\
Almanya & 69,0 & 30,0 & 39,0 & 0,0 & Kosta Rika & 51,5 & 34,3 & 17,2 & \\
AB ort. & 68,2 & & & & Meksika & 44,8 & & & \\
Polonya & 67,6 & 61,0 & 6,6 & 0,0 & Türkiye & 30,0 & 21,5 & 8,5 & \\
\hline
\end{tabular}

Kaynak: OECD (2018a)

Yarı zamanlı ya da tam zamanlı istihdam tercihleri ayrımına bakılmaksızın çalışan annelerin istihdam oranlarında özellikle 2000 'li yıllardan itibaren artış yaşanmıştır ve kadınların anne olduklarında çalışma hayatından çekildikleri görüşünün (Lundborg ve diğerleri, 2014) aksine 0-14 yaş arası çocuk sahibi çalışan annelerin istihdam oranları diğer kadın çalışanlardan daha yüksek seviyelerde gerçekleşmiştir.

2003 ve 2014 yılları arasında OECD üyesi 18 ülkenin toplam 0-14 yaş arası çocuk sahibi olan ve olmayan kadın çalışan oranları incelendiğinde her iki oranın da on yıllık zaman zarfında artış eğilimine girdiği görülmektedir (Tablo 2).

Tablo 2. 2003-2014 Yılları Arasındaki Çalışan Anne Eğilimleri (OECD-18)

\begin{tabular}{ccc}
\hline \hline & $\begin{array}{c}\text { O-14 yaş arasında çocuk sa- } \\
\text { hibi olmayan 15-64 yaş arası } \\
\text { kadınların istihdam oranları }\end{array}$ & $\begin{array}{c}\text { 0-14 yaş arasında en az bir } \\
\text { çocuğu olan 15-64 yaş arası } \\
\text { kadınların istihdam oranları }\end{array}$ \\
\hline 2003 & 56,52 & 64,13 \\
2004 & 56,94 & 64,56 \\
2005 & 58,00 & 65,15 \\
2006 & 58,86 & 66,29 \\
2007 & 59,71 & 66,76 \\
2008 & 60,12 & 67,71 \\
2009 & 59,18 & 66,40 \\
2010 & 58,54 & 66,07 \\
2011 & 58,55 & 66,09 \\
2012 & 58,82 & 66,27 \\
2013 & 59,11 & 66,35 \\
2014 & 59,79 & 67,25 \\
\hline
\end{tabular}

Not: OECD’ye üye 18 ülke; Avustralya, Belçika, Kanada, Çek Cumhuriyeti, Estonya, Yunanistan, Macaristan, Litvanya, Lüksemburg, Hollanda, Yeni Zelanda, Portekiz, Slovakya, Slovenya, İspanya, İsviçre, Birleşik Krallık ve ABD.

Kaynak: OECD (2018a)

Tablo 2'de ortalaması verilen 18 OECD ülkesinde hatırı sayılır oranda işgücüne katılım olmasına rağmen 2003-2014 yılları arasında toplam 0-14 yaş arası çocuk sahibi olan ve olmayan kadınla- 
rın oranı yaklaşık üç puanlık bir artış göstermiştir. Ancak 0-14 yaş arası çocuk sahibi olan çalışan anneler, 0-14 yaş arası çocuk sahibi olmayan kadınlardan \% 7-8 oranında fazladır. Diğer taraftan Türkiye'de istihdam oranlarının 2004-2013 yılları arasındaki değişimi de oldukça önemlidir. Türkiye'de 0-14 yaş arasında çocuk sahibi olmayan kadınların işgücüne katıım oranı 2004 yılında \% 23,3, 2013 yılında ise 6 puan artışla \% 29,4 olarak belirlenirken 0-14 yaş arası en az bir çocuk sahibi olan kadınların işgücüne katılım oranı 2004 yılında \% 21 iken 2013 yılında 9 puan artışla \% 30 oranına ulaşmıştır (OECD, 2018a). Hali hazırda işgücüne katııı oranları açısından 0-14 yaş arası çocuğu olan ve olmayan kadınların arasında büyük bir fark bulunmamaktadır. Ek olarak kadınların annelik ve çalışma hayatını bir arada yürütmeyi tercih oranları artış eğilimine girmiştir ve özellikle yüksek eğitim seviyesine sahip kadınlarda bu oran çok daha yüksektir (\% 65,5) (OECD, 2018a).

İstihdam oranlarının 0-14 yaş arası çocuk sahibi olan kadınlarda daha yüksek olmasının nedenleri arasında esnek çalışma biçimlerinin yaygınlaşmasının yanı sıra özellikle küçük yaştaki çocuklar için bakım hizmetlerinin sağlanması ve doğum izinlerinin düzenlenmiş olması, fark yaratan önemli unsurlar olarak ortaya çıkmaktadır.

Tablo 3. Ücretli Annelik İzinleri ve Ücret Oranları (2016)

\begin{tabular}{|c|c|c|c|c|c|c|c|}
\hline & $\begin{array}{l}\text { Istihdam } \\
\text { oranı }\end{array}$ & $\begin{array}{l}\text { Ücretli } \\
\text { izin } \\
\text { süresi } \\
\text { (hafta) }\end{array}$ & $\begin{array}{l}\text { Ücret } \\
\text { oranı } \\
(\%)\end{array}$ & & $\begin{array}{l}\text { Istihdam } \\
\text { oranı }\end{array}$ & $\begin{array}{l}\text { Ücretli } \\
\text { izin } \\
\text { süresi } \\
\text { (hafta) }\end{array}$ & $\begin{array}{l}\text { Ücret } \\
\text { oranı } \\
(\%)\end{array}$ \\
\hline İsveç & 83,1 & 12,9 & 77,6 & Birleşik Krallık & 67,1 & 39 & 30,9 \\
\hline Danimarka & 82 & 18 & 53,6 & OECD-31 ort. & 66,2 & 18 & - \\
\hline Norveç & 81,4 & 13 & 97,9 & Romanya & 65,8 & 18 & 85 \\
\hline Slovenya & 79,1 & 15 & 100 & $\mathrm{ABD}$ & 65,7 & 0 & 0 \\
\hline İsviçre & 77,5 & 14 & 56,4 & Estonya & 65,5 & 20 & 100 \\
\hline Litvanya & 75,8 & 16 & 80 & Bulgaristan & 65,3 & 58,6 & 78,4 \\
\hline Avusturya & 75,7 & 18 & 42,3 & Japonya & 63,2 & 14 & 67 \\
\hline Portekiz & 75,7 & 6 & 100 & Yeni Zelanda & 63,2 & 18 & 42,6 \\
\hline Hollanda & 74,8 & 16 & 100 & Avustralya & 62,9 & 16 & 100 \\
\hline Lüksemburg & 74,8 & 16 & 100 & Çek Cumhuriyeti & 61,6 & 28 & 62,6 \\
\hline Kanada & 73,7 & 17 & 48,4 & İrlanda & 60,2 & 26 & 34,3 \\
\hline Finlandiya & 73,6 & 17,5 & 74,4 & İspanya & 59,5 & 16 & 100 \\
\hline Belçika & 72,4 & 15 & 64,1 & Macaristan & 58,1 & 24 & 70 \\
\hline Fransa & 72,2 & 16 & 94,2 & Malta & 56,8 & 18 & 87 \\
\hline İsrail & 72,1 & 14 & 100 & Slovakya & 56,6 & 34 & 70 \\
\hline Litvanya & 70,1 & 18 & 100 & İtalya & 55,3 & 21,7 & 80 \\
\hline Kıbris & 69,6 & 18 & 75,2 & Şili & 54,9 & 18 & 100 \\
\hline Hırvatistan & 69,2 & 30 & 100 & Yunanistan & 52,2 & 43 & 54,2 \\
\hline Almanya & 69 & 14 & 100 & Kosta Rika & 51,5 & 17,3 & 100 \\
\hline$A B$ ort. & 68,2 & 21,8 & - & Meksika & 44,8 & 12 & 100 \\
\hline Polonya & 67,6 & 20 & 100 & Türkiye & 30 & 16 & 66 \\
\hline
\end{tabular}


Kaynak: OECD (2018a)

2000 'li yıllardan itibaren ülkelerin politikalarında da gerek ücretli ve ücretsiz annelik izinlerine ilişkin uygulamalara, gerek kaliteli ve düşük maliyetli erken çocuk bakımı ve eğitimi hizmetlerine yönelik düzenlemelere ağılık verilmiştir (Brewer, Cattan ve Crawford, 2014). Ülkelere göre ücretli annelik izinleri ve izin süresince anneye ödemesi yapılan ücret oranları Tablo 3'te gösterilmiştir. Ücretli annelik izinlerinin AB ortalaması 21,8, OECD ortalaması ise 18 haftadır. Ücretli izin süresi en uzun olan ülkeler arasında 58,6 hafta ile Bulgaristan, 43 hafta ile Yunanistan, 39 hafta ile Birleşik Krallık yer almaktadır. Ancak çok uzun sürelerle çalışma hayatından uzak kalmak annenin dünyaya yeni getirdiği bebeğinin bakımını sağlamak açısından avantaj gibi görünse de mesleki gelişim, terfi gibi olanaklar üzerinde olumsuz etki yaratacaktır. Diğer taraftan yasal ücretli izin hakkı tanımayan ABD istisna yaratırken en kısa süreli ücretli izinler ise Portekiz (6 hafta), Meksika (12 hafta), İsveç (12,9 hafta) gibi ülkelerde görülmektedir. Bu sürelerin kısa olması ise gerek annenin doğumdan sonra fiziksel ve psikolojik açıdan kendisini toparlaması gerekse bebeğiyle yeterince vakit geçirememesi bakımından sorun teşkil etmektedir. Çalışan anneyi çalışma hayatından çok uzun sürelerle uzak tutmayacak ve anneyi de yeni doğandan kısa sürede ayırmayacak makul sürede (16-18 hafta) annelik izinleri, çalışma hayatı ve anneliği uyumlu hale getirmek için ideal görünmektedir.

Annelik nedeniyle çalışma hayatından belirli bir süre uzakta kalmanın yaratacağı gelir kaybı, ücretin belirli bir oranının ya da tamamının ödenmesi ile telafi edilmektedir. Slovenya, Portekiz ve Hollanda'nın aralarında bulunduğu 15 ülkede ücretli annelik izni süresince ücretin tamamı ödenmektedir. Ücretli izin süresince ücret ödenme oranı en düşük ülkeler arasında ise Birleşik Krallık (\% 30,9), İrlanda (\% 34,3), Avusturya (\% 42,3) bulunmaktadır. Ücretin düşük bir orandaki miktarının ödenmesi maddi sıkıntı yaratabileceği için kadınları vaktinden önce işe dönüş zorunluluğu ile karşı karşıya bırakabilmektedir. Kadınların annelik sonrası istihdam oranlarında ve işe dönüş sürelerinde ücretli izin süreleri ve izin süresince ödenen ücret oranlarının da etkisi olmakla birlikte erken çocuk bakımı ve eğitimi hizmetlerinin düşük maliyetli, kaliteli ve erişilebilir olması belirleyici olmaktadır.

1980 ve 2014 yılları arasında geçen süre zarfında pek çok ülke, ücretli annelik ve ebeveynlik izinleri uygulamalarını yürürlüğe koymuş ve aynı zamanda erken çocuk bakımı ve eğitimi (EÇEB) hizmetleri genişletilmiştir. İşgücüne katılım ve toplam doğurganlık oranları arasındaki ters orantı özellikle İskandinav ülkelerinde de görüldüğü üzere EÇEB hizmetlerinin yaygınlaşmasının doğurganlık oranlarının artmasını sağlaması ile doğru orantılı hale gelmiştir. Özellikle EÇEB hizmetlerinin genişlemesi 0-2 yaş arasında çocukları olan çalışan annelerin çocuk bakımı konusunda yaşadıkları sorunları büyük ölçüde ortadan kaldırıken, uygun maliyetli ve kaliteli çocuk bakım hizmetlerinin erişilebilir olmaması birçok kadının çocukları 2 yaşına gelinceye kadar çalışma hayatının dışına çıkmasına neden olabilmektedir (OECD, 2017, s. 53).

Literatürde yer alan kadınların çalışma hayatına katıımının toplam doğurganlık oranları üzerinde olumsuz etkiler yarattığı görüşünün aksine makro düzeyde incelendiğinde doğurganlık oranları ve istihdam arasındaki korelasyonun değiştiği görülmektedir (Ahn ve Mira, 2002; Del Boca ve 
Locatelli, 2006). Diğer bir deyişle kadınların işgücüne katılımı, toplam doğurganlık oranlarını azaltmamaktadır. Kadınlar, genel olarak annelikten vazgeçmezken çalışma hayatını da sürdürme eğilimine girmiştir. Zira hem iş ve aile dengesini sağlama olanaklarında yelpazenin genişlemesi-yarı zamanlı çalışma, erken çocuk bakımı ve eğitimi hizmetlerinin yaygınlaşması vb.- hem de mesleki gelişim, gelir ve özgüven kazandıran iş imkânlarının artması kadınlar arasında anne olduktan sonra da çalışma hayatını sürdürmeyi tercih edenlerin oranı arttırmıştır.

Tablo 4. Ülkelere Göre Kadın İstihdam Oranları ve Toplam Doğurganlık Oranları Arasındaki Ilişki (1980 - 2014)

\begin{tabular}{|c|c|c|c|c|c|}
\hline 1980 & $\begin{array}{l}25-54 \text { yaş } \\
\text { arası } \\
\text { kadınların } \\
\text { istihdam } \\
\text { oranı }\end{array}$ & $\begin{array}{l}\text { Toplam } \\
\text { doğurganlık } \\
\text { oranı }\end{array}$ & 2014 & $\begin{array}{l}25-54 \text { yaş } \\
\text { arası } \\
\text { kadınların } \\
\text { istihdam } \\
\text { oranı }\end{array}$ & $\begin{array}{l}\text { Toplam } \\
\text { doğurganlık } \\
\text { oranı }\end{array}$ \\
\hline Avustralya & 50,3 & 1,9 & Avustralya & 72 & 1,8 \\
\hline Belçika ${ }^{1}$ & 45,8 & 1,7 & Belçika & 74,9 & 1,7 \\
\hline Kanada & 55,9 & 1,7 & Kanada ${ }^{4}$ & 77,4 & 1,6 \\
\hline Danimarka & 77 & 1,5 & Danimarka & 78,4 & 1,7 \\
\hline Finlandiya & 79,8 & 1,6 & Finlandiya & 78 & 1,7 \\
\hline Fransa ${ }^{1}$ & 61,7 & 1,9 & Fransa & 76,2 & 2 \\
\hline Almanya & 54,5 & 1,6 & Almanya & 78,8 & 1,5 \\
\hline Yunanistan ${ }^{1}$ & 40,1 & 2,2 & Yunanistan & 53,1 & 1,3 \\
\hline İrlanda ${ }^{1}$ & 30,3 & 3,2 & İrlanda & 66,6 & 2 \\
\hline İsrail ${ }^{2}$ & 51,7 & 3,1 & İsrail & 74,3 & 3,1 \\
\hline İtalya & 37,1 & 1,7 & İtalya & 57,6 & 1,4 \\
\hline Japonya & 55,5 & 1,8 & Japonya & 71,8 & 1,4 \\
\hline Kore & 47 & 2,8 & Kore & 62,7 & 1,2 \\
\hline Lüksemburg ${ }^{1}$ & 39,3 & 1,5 & Lüksemburg & 76,8 & 1,5 \\
\hline Hollanda & 35,6 & 1,6 & Hollanda & 76,5 & 1,7 \\
\hline Yeni Zelanda ${ }^{3}$ & 65,4 & 2 & Yeni Zelanda & 74,9 & 1,9 \\
\hline Norveç & 67,8 & 1,7 & Norveç & 81,4 & 1,8 \\
\hline Portekiz & 50,2 & 2,2 & Portekiz & 74,3 & 1,2 \\
\hline İspanya & 28,5 & 2,2 & İspanya & 62,3 & 1,3 \\
\hline İsveç & 81,5 & 1,7 & İsveç & 82,8 & 1,9 \\
\hline Birleşik Krallık ${ }^{1}$ & 61,3 & 1,9 & $\begin{array}{l}\text { Birleşik Kral- } \\
\text { lık }\end{array}$ & 76,1 & 1,8 \\
\hline $\mathrm{ABD}$ & 60,1 & 1,8 & $\mathrm{ABD}$ & 70 & 1,9 \\
\hline
\end{tabular}

1. Referans yllı 1983. 2. Referans yılı 1985. 3. Referans yılı 1986. 4. Referans yılı 2013. Kaynak: OECD (2018a; 2018b)

Tablo 4 incelendiğinde Finlandiya dışındaki tüm ülkelerde kadın istihdam oranlarının arttığı görülmektedir. 1980 yılı verileri incelendiğinde, diğer ülkelere kıyasla kadın işgücüne katııım oranının 
daha yüksek olduğu ülkelerin büyük bir kısmında doğurganlık oranlarının düşük olduğu görülmektedir. Ancak aradan geçen yaklaşık yirmi beş yıllık sürede bu eğilim tersine dönerek 2014 yllında, düşük doğurganlık oranlarına sahip ülkelerde kadın istihdam oranlarının da düşük seviyede olduğu bir tablo ortaya çıkmıştır. Kadınların işgücü piyasasına katılımı ve anneliğin bir arada yürütülmesiyle ilgili sorun yaşanan ülkeler olsa da bu sorunun yarattığı sıkıntılar azalmaya başlamıştır.

Özellikle Akdeniz ülkeleri (Yunanistan, İtalya, Portekiz ve İspanya) ve Kore'de kadın işgücüne katılım oranları artarken toplam doğurganlık oranları azalmıştır. Bu durum, istihdam ve anneliği bir arada yürütmenin zorluklarının bu ülkelerde tam olarak aşılamadığının bir göstergesi olarak yorumlanabilir. Diğer taraftan çalışma hayatı ve anneliğin en uyumlu şekilde bir arada yürütüldüğü ülkeler ise İskandinav ülkeleridir.

\section{Sonuç}

Kadınlar, dünyaya çocuk getirmek gibi değiştirilemez bir biyolojik yetiye sahip olmaları nedeniyle anne olmaları halinde çalışma hayatında diğer tüm cinsiyete dayalı eşitsizlikler ortadan kalksa bile bir takım sorunlarla karşı karşıya kalmaktadır. Gerek sosyal kimliklerin çatışması gerek annelik ideolojilerinin yarattığı baskı bu sorunların büyüklük derecesini arttırmaktadır. Özellikle anne ve çalışan kimlikleri birbirinden farklı ideolojik arka plana ve uygulama alanına sahiptir. Bu kimliklerin gerektirdiği roller diğer rolün tutumları, davranışları, beklentileri ile çatışmaya girmektedir.

Son yirmi yıldır çalışma hayatına katılan kadınların sayısında hatırı sayılır bir artış gerçekleşmiş bu doğrultuda çalışan anne sayısı da artış eğilimine girmiştir. Çalışma hayatı ile anneliği bir arada yürüten kadınların 2014 yılında OECD ortalaması; \% 66,2, AB ortalaması ise \% 68,2'dir. Kadınların çalışma hayatına dâhil olmaları halinde doğurganlık oranlarının azalacağı iddiasının aksine birçok ülkede doğurganlık oranları artmıştır. Diğer taraftan çocuk sahibi olma oranlarının en yüksek olduğu 25-29 yaş arasında bulunan kadınların istihdam oranının da \% 64 civarında olması ve 0-14 yaş arası çocuk sahibi olan annelerin istihdam oranının, bu yaş grubunda çocuğu bulunmayan annelerin istihdam oranlarından 7-8 puan yüksek olması da annelik nedeniyle istihdam oranlarının azalmadığının kanıtı niteliğindedir. Dolayısıyla emekliliğe değin kesintisiz bir çalışma hayatı sürdürmesi beklenen "çalışan" ve çocuklarına tüm hayatını adaması beklenen "anne" kimlikleri birbirleri üzerinde aşınmalar yaratarak "çalışan anne" şeklinde yeni bir senteze dönüşmüştür.

Bu durum, özellikle tam zamanlı ve yoğun anneliği dikte eden ideolojilerin hâkim olduğu toplumlarda ve kesimlerde anneliğin aşınması olarak yorumlanırken bu ideolojiye karşı çıkan kadınların sayısının her geçen gün artmasının yanı sıra hükümetlerin iş ve aile hayatını uyumlulaştırmaya yönelik ücretli doğum izni, ebeveynlik izni ve kısmi süreli çalışma olanağı gibi yasal düzenlemeler yapması ve erken çocuk bakım hizmetlerinin genişlemesi, çalışan anne ideolojisinin pek çok toplumda yaygınlaşmasına olanak tanımıştır. 


\section{Kaynaklar}

Ahn, N. ve Mira, P. (2002). A note on the changing relationship between fertility and female employment rates in developed countries. Journal of Population Economics, 15(4), 667-682. Erişim Adresi: https://www.jstor.org/stable/20007839

Badinter, E. (2011). Kadınlık mı annelik mi. A. Ekmekçi (Çev.). İstanbul: İletişim Yayınları.

Bassin, D., Honey, M. ve Kaplan, M. M. (Ed.). (1996). Representations of motherhood. Yale University Press.

Blau, F. D. ve Kahn L. M. (2007). Changes in the labor supply behavior of married women: 19802000. Journal of Labor Economics, 25(3), 393-438.

Blundell, R., Bozio, A. ve Laroque, G. (2011). Extensive and intensive margins of labour supply: Working hours in the US, UK and France. IFS Working Paper 01. Institute for Fiscal Studies. Erişim Adresi: https://www.ifs.org.uk/docs/bozio_0311.pdf

Bowlby, J. (1969). Attachment. New York: Basic Books.

Brewer, M., Cattan, S. ve Crawford, C. (2014). The IFS Green Budget. Institute for Fiscal Studies.

Coulter, M. (2010). Essentialism and mothering. A. O'Reilly (Ed.), Encyclopedia of motherhood içinde (s. 358-360). Thousand Oaks, CA: SAGE Publications, Inc.

Cristia, J. P. (2008). The effect of a first child on female labor supply: evidence from women seeking fertility services. Journal of Human Resources, 43(3), 487-510. doi: 10.3368/jhr.43.3.487

Dainton, M. (1993). The myths and misconceptions of the stepmother identity: Descriptions and prescriptions for identity management. Family Relations, 42(1), 93-98. doi: 10.2307/584928

Del Boca, D. ve Locatelli, M. (2006). The determinants of motherhood and work status: A survey. IZA Discussion Papers, No. 2414, Bonn: Institute for the Study of Labor (IZA). Erişim adresi: http://anon-ftp.iza.org/dp2414.pdf

Dillaway, H. ve Paré, E. (2008). Locating mothers: How cultural debates about stay-at-home versus working mothers define women and home. Journal of Family Issues, 29(4), 437-464. doi: $10.1177 / 0192513 \times 07310309$

DiQuinzio, P. (1999). The impossibility of motherhood: Feminism, individualism, and the problem of mothering. New York: Routledge.

Douglas, S. J. ve Michaels, M. W. (2004). The mommy myth: The idealization of motherhood and how it has undermined women. New York, NY: Free Press. 
Eda KILIÇ

Fagan, C. and Norman, H. (2012). Trends and social divisions in maternal employment patterns following maternity leave in the UK. International Journal of Sociology and Social Policy, 32(9/10), 544-560. doi: $10.1108 / 01443331211257643$

Finley, L. M. (1986). Transcending equality theory: A way out of the maternity and the workplace debate. Columbia Law Review, 86(6), 1118-1182. doi: 10.2307/1122655

Garey, A. I. (2008). Motherhood. J. O'Brien (Ed.), Encyclopedia of gender and society içinde (s. 583588). Thousand Oaks, CA: Sage Publications, Inc.

Glenn, E. N. (1994). Social construction of mothering: A thematic overview. E. N. Glenn, G. Chang ve L. R. Forcey (Ed.), Mothering: Ideology, experience and agency içinde (s. 1-29). New York \& London: Routledge.

Goldin, C. (2006). The quiet revolution that transformed women's employment, education, and family. American Economic Review, 96(2), 1-21. doi: 10.1257/000282806777212350

Goldin, C. ve Katz, L. F. (2002). The power of the pill: Oral contraceptives and women's career and marriage decisions. Journal of Political Economy, 110(4), 730-770. doi: 10.1086/340778

Green, F. J. (2010). Mask of motherhood. A. O'Reilly (Ed.), Encyclopedia of Motherhood içinde (s. 692-693). Thousand Oaks, CA: Sage Publications, Inc.

Hall, C. (1992). White, male, and middle-class: Explorations in feminism and history. New York: Routledge.

Haynes, K. (2008). Transforming identities: Accounting professionals and the transition to motherhood.Critical Perspectives on Accounting, 19(5), 620-642. doi: 10.1016/j.cpa.2006.10.003

Hays, S. (1996). The cultural contradictions of motherhood. New Haven, CT: Yale University Press.

Johnston, D. D. ve Swanson, D. H. (2006). Constructing the "good mother": The experience of mothering ideologies by work status. Sex Roles, 54(7-8), 509-519. doi: 0.1007/s11199-0069021-3

Joshi, H., Macran, S. ve Dex, S. (1996). Employment after childbearing and women's subsequent labour force participation: Evidence from the British 1958 birth cohort. Journal of Population Economics, 9(3), 325-348. doi: 10.1007/BF00176691

Joshi, H., Paci, P. ve Waldfogel, J. (1999). The wages of motherhood: Better or worse?. Cambridge Journal of Economics, 23(5), 543-564. doi: 10.1093/cje/23.5.543

Lerner, G. (1986). The creation of patriarchy. New York: Oxford University Press. 
Lewis, S. (1991). Motherhood and employment: The impact of social and organizational values. A. Phoenix, A. Woollett ve E. Lloyd (Ed.), Motherhood: meanings, practices and ideologies içinde (s. 195-215). London: Sage Publications, Inc.

Lundborg, P., Plug, E. ve Rasmussen, A. W. (2014). Fertility effects on female labor supply: IV evidence from IVF treatments. IZA Discussion Papers, No. 8609, Bonn: Institute for the Study of Labor (IZA). Erişim adresi: http://anon-ftp.iza.org/dp8609.pdf

Lupton, D. (2000). 'A love/hate relationship': The ideals and experiences of first-time mothers. Journal of Sociology, 36(1), 50-63. doi: 10.1177/144078330003600104

McGlynn, C. (2000). Ideologies of motherhood in European community sex equality law. European Law Journal, 6(1), 29-44. doi: 10.1111/1468-0386.00094

Miller, T. (2005). Making sense of motherhood: A narrative approach. New York: Cambridge University Press.

Miller, T. (2007). "Is this what motherhood is all about?": Weaving experiences and discourse through transition to first-time motherhood. Gender \& Society, 21(3), 337-358. doi: $\underline{10.1177 / 0891243207300561}$

Hallstein, D. L. O. (2010). Public choices, private control: How mediated mom labels work rhetorically to dismantle the politics of choice and white second wave feminism successes. S. Hayden ve D. L. O. Hallstein (Ed.), Contemplating maternity in an era of choice: Explorations into discourses of reproduction içinde (s. 5-26). New York: Lexington Books.

O'Reilly, A. (Ed.) (2007). Maternal theory: Essential readings. Toronto: Demeter Press.

OECD (2017). Starting Strong 2017: Key OECD Indicators on Early Childhood Education and Care. Paris: OECD Publishing. doi: 10.1787/9789264276116-en

OECD (2018a). OECD Family Database. Paris: OECD Erişim adresi: http://www.oecd.org/social/family/database.htm

Organisation for Economic Co-operation and Development. (2018b). OECD Employment Database. Paris: OECD. Erişim adresi: http://www.oecd.org/employment/emp/onlineoecdemploymentdatabase.htm

Pickert, K. (2012). The man who remade motherhood. Time, 179(20), 32-39.

Rich, A. (1977). Of woman born: Motherhood as experience and institution. London: Virago.

Risman, B. J. (1998). Gender as structure. Gender vertigo: American families in transition içinde (s. 292-299). Erişim adresi: http://users.clas.ufl.edu/kristinjoos/sum03/wst3015/risman.pdf

Rothman, B. K. (1989). Recreating motherhood: Ideology and technology in a patriarchal society. New York: WW Norton \&Company. 
Eda KILIÇ

Rothman, B. K. (1994). Beyond mothers and fathers: Ideology in a patriarchal society. N. E. Glenn, G. Chang, ve R. L. Forcey (Ed.), Mothering: Ideology, Experience, and Agency içinde (s. 139157). New York and London: Routledge.

Walby, S. (1990). Theorising patriarchy. Oxford: Blackwell. 